\title{
Decision Support Approaches in Adaptive Forest Management
}

\author{
Jan Kašpar ${ }^{1, *}$, Pete Bettinger ${ }^{2}$ (1) , Harald Vacik ${ }^{3}$, Róbert Marušák ${ }^{1}$ (i) and Jordi Garcia-Gonzalo ${ }^{4}$ \\ 1 Department of Forest Management, CULS Prague, Kamýcká 129, 16500 Praha-Suchdol, Czech Republic; \\ marusak@fld.czu.cz \\ 2 Warnell School of Forestry and Natural Resources, University of Georgia, 180 East Green Street, \\ Athens, GA 30602, USA; pbettinger@warnell.uga.edu \\ 3 Institute of Silviculture, University of Natural Resources and Applied Life Sciences, 1180 Vienna, Austria; \\ harald.vacik@boku.ac.at \\ 4 Forest Sciences Centre of Catalonia (CTFC), Ctra. Sant Llorenç de Morunys, Km 2, 25280 Solsona, Spain; \\ j.garcia@ctfc.cat \\ * Correspondence: kasparj@fld.czu.cz; Tel.: +420-224-382-818 \\ Received: 9 April 2018; Accepted: 16 April 2018; Published: 18 April 2018

\begin{abstract}
Climate and social changes place strong demands on forest managers. Forest managers need powerful approaches and tools, which could help them to be able to react to the rapidly changing conditions. However, the complexity of quantifying forest ecosystems services as well as the complexity of current decision theories, technologies and operation research methods, complicate the creation of one general tool. The continuous research and development in this area is an indispensable part of the success of adaptive management as well as the sharing of knowledge and information between research teams around the world. The Community of Practice of Forest Management Decision Support Systems provides a platform for broad discussion among scientists, researchers as well as forest professionals. This special issue provides papers which resulted from a conference session of the International Union of Forest Research Organizations' (IUFRO) 125th Anniversary Congress in Freiburg, Germany in 2017. The joint sessions and other meetings (and resulting publications) are appropriate opportunities for knowledge sharing on these important methods and systems for protecting and managing forest ecosystems in the future.
\end{abstract}

Keywords: ecosystem services; decision-making; climate change; decision support systems

\section{Introduction}

Current human society faces potential consequences of climate change, which are negative in most cases. Although climate change and warming could have a positive effect on future forest productivity, expected negative effects in the form of frequent extreme weather events (heat waves, droughts and storms) are considered to be increasingly important stress factors for forests, along with potential increases in pathogen attacks. To know and predict impacts of these changes on forest ecosystems helps us to potentially avoid unexpected and undesirable developments in forest ecosystems. This is also a topic of high-political discussions. In the Madrid Ministerial Declaration and the Ministerial Resolution 2 Protection of forests in changing environment, adopted at the Seventh Ministerial Conference on the Protection of Forests in Europe, awareness was expressed among the European countries about changing climate patterns and associated natural hazards. Moreover, the ministers committed themselves to increase the work on adaptation of forests and forest management to climate change to prevent and mitigate damages caused by changing conditions at the local and regional scales in order to secure all functions of European forests, including their resilience to natural hazards and protection against human-induced threats, and maintain their productive and protective functions. 
There are two basic tasks for society in response to reducing these negative consequences: to mitigate the climate change impact and to adapt forest management practices for climate change. The most amount of attention seems to have been paid to mitigation in the last decade, mainly by efforts at reducing the greenhouse gases (GHGs). However, adaptation, defined as adjustment in natural or human systems in response to actual or expected climate change or its effects [1], is becoming more and more a current topic. Adaptive forest management can help forest ecosystems to adjust to new conditions while maintaining desired forest ecosystem services and reducing the risks of forest degradation [2].

Adaptive forest management requires adaptive decision-making to develop optimal management strategies considering effects of climate change. Interest in adaptive decision-making, as an approach for simultaneously managing and learning about natural resources, has grown steadily over the last decade [3]. Even so, there are still many gaps in scientific knowledge in the field of decision-making, decision support approaches and systems reflecting changing conditions.

Some of the gaps in forest management research for the 21st century consist of ecological, economic and social uncertainties that influence the long-term planning. Decision makers are facing several challenges in making a choice about a suitable combination of forest management goals, the best management option, or possible pathways to make forests less vulnerable and highly resistant according to expected negative impacts of climate change. External factors are often stochastic in nature and the options for adaption are numerous. Rising demands from society regarding a sustainable provision of ecosystems services increases the complexity of forest decision problems as well.

In this context the application of decision support tools can help to improve the ability of the decision maker to make rational decisions, use resources efficiently and manage forests effectively. The potential for the development of decision support approaches in forest management is facilitated by decision theory, technology, and operations research methods. Demands for decision support are emerging as the challenges and problems in forest management are rising steadily. However, considering the large uncertainties regarding future environmental conditions and the evolving societal demands, decision support approaches are seen as very promising for facilitating strategic ecosystem management planning processes. Nowadays, Decision Support Systems (DSS) can play a significant role in analyzing the needs of adaptation of forest management strategies and can support policy makers in making appropriate decisions.

During the International Union of Forest Research Organizations' (IUFRO) 125th Anniversary Congress in Freiburg in autumn 2017, a session explored how the field of DSS is currently expanding under different contexts. This Special Issue provides an overview on how DSS are designed and applied for supporting adaptive forest management, and includes an overview on models, methods and techniques.

\section{Decision Support Approaches}

Acosta and Corral [4] provide a thorough review of multicriteria decision support analysis and participatory decision support systems with respect to their use in forest management, and describe the influence of various actors on learning processes and knowledge generation. Bettinger and Boston [5] provide a review and opinion on the opportunities to enhance forest planning heuristics, given their experience in this area over the last 20 years. Potential avenues to enhance the effectiveness of heuristic search processes were proposed in association with the need to address adaptive forest management problems. Yamada and Yamaura [6] designed a specific decision-support model using a Bayesian network to simulate the zoning of potential forest management activities in Japan. In this example of using a multi-criteria framework, forest production outcomes (timber) were considered simultaneously with other forest ecosystem services (soil protection, biodiversity, carbon sequestration) in an effort to examine the trade-offs among the various societal goals. Thompson et al. [7] describe an optimization-simulation model that was designed to address wildfire-related forest management opportunities in the western United States (California). Forest management regimes were 
optimized while potential fire effects were simulated in this decision-support system that facilitated an examination of budgetary constraints. Radl et al. [8] describe the development of a Bayesian model designed to inform management planning processes that recognize natural disturbances (wind events and insect outbreaks). The model was applied in a case study to forests of southern Austria in an effort to analyze the trade-offs among management options of Norway spruce (Picea abies). Finally, as a reflection of the international nature of Forests, da Silva et al. [9] describe a mathematical programming approach to determining the optimal location of wood storage yards in Brazil while taking into account characteristics of the landscape. Each of these papers aimed to further our capability as a society to promote and advance sustainable forest management.

\section{Conclusions}

Several conferences related to DSS in forest management (Vienna 2003, Edinburgh 2005, Lisbon 2009, Umea 2013, Salt Lake City 2014) have provided a sound basis for decision support and applications in a wider context [10-12]. In the last years, there is a trend towards technical and methodological improvements observed that allow the design of sophisticated and complex applications [13]. The papers of this special issue provide an overview about the different models, methods and techniques applied to support decision making in adaptive forest management. The challenges that have to be tackled by decision analysts and researchers in tailoring the DSS to the needs of the decision makers allow estimation of the complexity of the tools presented.

Decision support approaches for adaptive forest management are a challenging research area due to the complexity of theory, technology, and operations research methods on the one side, and ecological, economic and social uncertainties of forest long-term planning on the other side. The research teams dealing with decision support approaches in the framework of current natural and social conditions should be interdisciplinary to adequately cover the whole spectrum of different aspects.

The exchange of experiences and lessons learned from the development and application of DSS is becoming more important as we enter the future. The Community of Practice of Forest Management Decision Support Systems has a well-established user community that discusses the challenges in the design and implementation of DSS [14]. The readers are therefore invited to contribute to the continuation of the network activities of the CoP in connecting and mobilizing developers and users of DSS to support the planning and sustainable use of forest resources in a changing world.

Acknowledgments: The authors would like to thank all authors contributing to this Special Issue and for providing insight on Forest Management Decision Support Approaches applied for the Adaptive Forest Management within the context of climate change. Special thanks goes to the journal editors of Forests for providing substantial support in handling the manuscripts and reviews. This special issue was supported by the project "Advanced research supporting the forestry and wood-processing sector's adaptation to global change and the 4th industrial revolution", reg. No. CZ.02.1.01/0.0/0.0/16_019/0000803.

Author Contributions: Jan Kašpar, Pete Bettinger, Harald Vacik, Róbert Marušák and Jordi Garcia-Gonzalo designed the contributions to the Special Issue and interpreted the results. All co-authors contributed to the writing of the Editorial.

Conflicts of Interest: The authors declare no conflicts of interest. The funding sponsors had no role in the design of the study; in the collection, analyses, or interpretation of data; in the writing of the manuscript, and in the decision to publish the results.

\section{References}

1. Intergovernmental Panel on Climate Change (IPCC). Climate Change 2001: Impacts, Adaptation and Vulnerability; IPCC Third Assessment Report; Cambridge University Press: Cambridge, UK, 2001.

2. Bolte, A.; Ammer, C.; Löf, M.; Madsen, P.; Nabuurs, G.-J.; Schall, P.; Spathelf, P.; Rock, J. Adaptive forest management in central Europe: Climate change impacts, strategies and integrative concept. Scand. J. For. Res. 2009, 24, 473-482. [CrossRef] 
3. Williams, B.K. Adaptive management of natural resources-framework and issues. J. Environ. Manag. 2011, 92, 1346-1353. [CrossRef] [PubMed]

4. Acosta, M.; Corral, S. Multicriteria decision analysis and participatory decision support systems in forest management. Forests 2018, 8, 116. [CrossRef]

5. Bettinger, P.; Boston, K. Forest planning heuristics-Current recommendations and research opportunities for s-metaheuristics. Forests 2017, 8, 476. [CrossRef]

6. Yamada, Y.; Yamaura, Y. Decision support system for adaptive regional-scale forest management by multiple decision-makers. Forests 2017, 8, 453. [CrossRef]

7. Thompson, M.P.; Riley, K.L.; Loeffler, D.; Haas, J.R. Modeling fuel treatment leverage: Encounter rates, risk reduction, and suppression cost impacts. Forests 2017, 8, 469. [CrossRef]

8. Radl, A.; Lexer, M.J.; Vacik, H. A Bayesian belief network approach to predict damages caused by disturbance agents. Forests 2018, 9, 15. [CrossRef]

9. Da Silva, E.F.; da Silva, G.F.; Figueiredo, E.O.; Binoti, D.H.B.; de Mendonça, A.R.; Torres, C.M.M.E.; Pezzopane, J.E.M. Allocation of storage yards in management plans in the Amazon by means of mathematical programming. Forests 2018, 9, 127. [CrossRef]

10. Rauscher, M.H.; Reynolds, K.M.; Vacik, H. Decision support systems for forest management. Comput. Electron. Agric. 2005, 49, 1-5. [CrossRef]

11. Borges, J.G.; Eriksson, L.O. Foreword: Special Issue: Decision support systems for sustainable forest management. Scand. J. For. Res. 2014, 29, 1. [CrossRef]

12. Vacik, H.; Borges, J.G.; Garcia-Gonzalo, J.; Eriksson, L.O. Decision Support for the Provision of Ecosystem Services under Climate Change: An Editorial. Forests 2015, 6, 3212-3217. [CrossRef]

13. Vacik, H.; Lexer, M.J. Past, current and future drivers for the development of decision support systems in forest management. Scand. J. For. Res. 2014, 29, 2-19. [CrossRef]

14. Community of Practice of Forest Management Decision Support Systems. Available online: http://www. forestdss.org (accessed on 9 April 2018).

(C) 2018 by the authors. Licensee MDPI, Basel, Switzerland. This article is an open access article distributed under the terms and conditions of the Creative Commons Attribution (CC BY) license (http:/ / creativecommons.org/licenses/by/4.0/). 